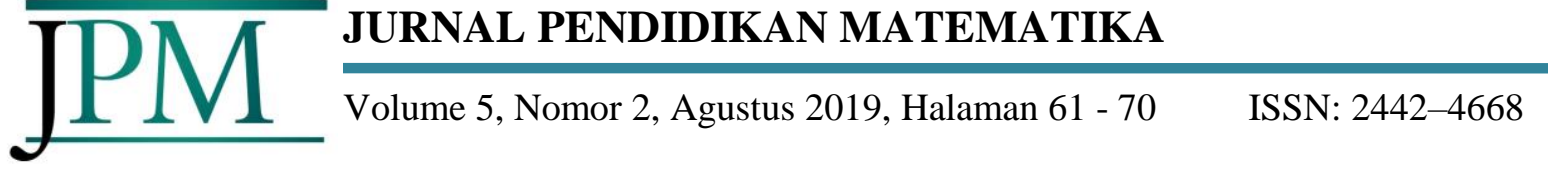

\section{PENILAIAN SIKAP DALAM PEMBELAJARAN MATEMATIKA}

\author{
${ }^{1}$ Kusaeri \\ ( ${ }^{1}$ Jurusan Pendidikan Matematika dan IPA UIN Sunan Ampel Surabaya) \\ E-mail: ${ }^{1}$ kusaeri@uinsby.ac.id
}

\begin{abstract}
Abstrak
Pendekatan penilaian pembelajaran matematika di Indonesia terus mengalami perubahan, seiring dengan diberlakukanya Kurikulum 2013. Perubahan tersebut dipicu oleh kecenderungan bergesernya penilaian pembelajaran matematika pada tataran global. Penilaian untuk mengungkap aspek pengetahuan dan keterampilan, relatif tidak ada kendala bagi sebagian besar guru. Namun, yang banyak dikeluhkan adalah bagaimana mengembangkan instrumen penilaian aspek sikap. Tulisan ini mengulas teknik penilaian untuk aspek sikap yang dapat digunakan sebagai acuan guru SD/MI, SMP/MTs, maupun SMA/MA mencakup penilaian melalui pengamatan (observasi), penilaian diri, penilaian antarteman, dan penilaian dengan jurnal.
\end{abstract}

Kata Kunci: penilaian sikap, matematika, sikap sosial, sikap spiritual

\section{PENDAHULUAN}

Saat ini, pendekatan penilaian matematika di seluruh dunia telah mengalami perubahan secara signifikan. Clarke (1996) menyatakan bahwa perubahan tersebut dipicu oleh dua hal, kurikulum matematika sekolah yang terus berubah dan teori-teori pembelajaran matematika yang juga terus berkembang. Perubahan dan evolusi penilaian pembelajaran matematika telah lama terjadi di Cina (Chen, 2011). Hal yang sama terjadi di Australia (Whatt, 2005). Perubahan penilaian tersebut lebih disebabkan tren perubahan penilaian pembelajaran matematika secara global.

Perubahan penilaian di level sekolah menengah juga terjadi di Korea (Park \& Park, 2012), menyusul perubahan kurikulum yang diterapkan di Korea pada 2009. Dalam dokumen perubahan tersebut, penilaian dalam pembelajaran matematika harus menggunakan berbagai teknik dan metode sehingga mampu memotret sikap, potensi dan keterampilan siswa dalam matematika (Kusaeri, 2019). Kondisi serupa terjadi di Indonesia. Semenjak diberlakukanya Kurikulum 2013, penilaian dalam pembelajaran matematika juga mengalami pergeseran. Tuntutan ranah penilaian menjadi semakin kompleks, tidak hanya memfokuskan pada penggalian aspek pengetahuan siswa. Namun, penilaian pembelajaran matematika juga harus mampu memotret keterampilan dan sikap siswa. Dalam aspek pengetahuan, lebih diarahkan penggalian potensi berpikir kritis dan kemampuan problem solving siswa (Kusaeri, 2014).

Berbagai studi yang disebutkan di atas secara jelas menunjukkan bahwa realitas penilaian pembelajaran matematika harus mampu mengimbangi dinamika perkembangan keimuan yang ada. Perubahan dan perkembangan paradigma itu tentu berimplikasi kepada cara-cara baru dalam penilaian. Penggunaan tes untuk mengukur hasil belajar siswa yang pada masa-masa lalu sangat mendominasi proses pembelajaran matematika di sekolah, tentunya sudah kurang memadai (Fulcher \& Davidson, 2007), karena bentuk-bentuk tersebut lebih menekankan pentingnya menilai pemahaman terhadap materi pelajaran matematika.

Konsep assessment driven instruction (Abidin, 2012) patut dipertimbangkan seiring perubahan aspek penilaian. Konsep assessment driven instruction merupakan sebuah konsep 
yang meyakini bahwa mutu proses pembelajaran di kelas matematika akan mampu meningkat dengan optimal jika pembelajaran dipandu oleh serangkaian kegiatan penilaian. Kegiatan penilaian tentu saja merupakan penilaian yang pada dasarnya dimaksudkan untuk menilai semua aktivitas yang dilakukan siswa selama pembelajaran. Jika siswa selama pembelajaran matematika hanya mendengarkan ceramah guru, dan siswa tidak pernah atau bahkan jarang diberi kesempatan melakukan manipulasi soal-soal matematika, maka proses pembelajaran matematika ini sebenarnya tidak sedang terjadi dalam kelas tersebut.

Peranan penilaian dalam hal ini adalah menentukan spesifikasi kegiatan yang harus dilakukan siswa, menentukan standar atas spesifikasi kegiatan tersebut, serta menentukan skoring bagi capaian yang diperoleh siswa selama beraktivitas tersebut. Peran ini diyakini akan mampu mendongkrak mutu proses pembelajaran matematika yang lebih berorentasi pada pembentukan sikap, kemampuan dan potensi siswa secara optimal. Wormeli (2006) mengemukakan bahwa penilaian otentik mampu mendidik guru menjadi model pembentukan sikap siswa dalam proses pembelajaran matematika. Hal ini sekaligus mampu mengembangkan karakter pada para siswa. Bukankah pembentukan sikap dapat dilakukan melalui pemodelan?

Dengan demikian, sudah saatnyalah penilaian digunakan sebagai pemandu proses pembelajaran. Melalui penilaian yang baik akan tercipta sebuah proses pembelajaran yang baik (Abidin, 2012). Untuk itu, berbagai teknik penilaian yang mampu memotret potensi dan kemampuan siswa secara komprehensif dalam matematika perlu diindahkan. Sebagaimana dalam Permendikbud Nomor 23 tahun 2016, untuk menilai aspek sikap dapat dilakukan melalui observasi dan teknik penilaian lain yang relevan. Sedangkan untuk menilai aspek keterampilan dapat dilakukan cara lain misalnya melalui praktik, produk, proyek, portofolio, dan/atau teknik lain sesuai dengan kompetensi yang dinilai.

Dalam tulisan ini akan fokus mengulas teknik penilaian sikap dalam pembelajaran matematika. Sebab, teknik penilaian untuk aspek pengetahuan dan keterampilan relatif tidak ada kendala. Mayoritas yang dikeluhkan guru adalah penilaian sikap (Retnawati, 2015). Lagi pula, wawasan guru dalam memilih dan mengembangkan instrumen penilaian aspek sikap masih kurang.

Untuk itulah, penting kiranya diuraikan konsep sikap. Sikap merupakan salah satu unsur kepribadian yang memengaruhi cara seseorang dalam bertindak dan bertingkah laku. Sikap seseorang terhadap suatu obyek atau orang lain yang dihadapinya, tercermin dari caranya bereaksi terhadap apa yang dihadapinya (Fernandes, 1984). Karenanya, sikap tidak berdiri sendiri. Sikap dapat dibagi menjadi tiga komponen, seperti disajikan dalam Tabel 1.

Tabel 1 Komponen Sikap

\begin{tabular}{ccl}
\hline No. & Komponen & \multicolumn{1}{c}{ Keterangan } \\
\hline 1. & Kognitif & $\begin{array}{l}\text { Komponen yang memiliki keterkaitan dengan aspek pengetahuan, } \\
\text { pandangan, keyakinan, yakni, berbagai hal yang berkaitan dengan } \\
\text { persepsi orang terhadap obyek sikap. } \\
\text { Komponen yang berhubungan dengan rasa senang atau tidak senang } \\
\text { terhadap obyek sikap, terkait dengan arah sikap, baik positif atau negatif. }\end{array}$ \\
2. & Afektif & $\begin{array}{l}\text { Komponen yang terkait kecenderungan bertindak terhadap obyek sikap, } \\
\text { yakni seberapa besar kecenderungan bertindak atau berperilaku } \\
\text { seseorang terhadap obyek sikap }\end{array}$ \\
3. Konatif atau \\
perilaku
\end{tabular}

Ketiga komponen di atas, dalam dimensi empiris mampu memengaruhi tindakan seseorang dalam bersikap. Tindakan seseorang sangat dipengaruhi oleh sikapnya terhadap obyek sikap yang dihadapi. Apabila seseorang bersikap positif terhadap suatu obyek sikap, maka akan menimbulkan perilaku yang positif, ditandai oleh kecenderungan tindakan untuk mendekati, menyenangi dan mengharapkan obyek sikap yang dihadapinya. Sebaliknya, 
apabila seseorang bersikap negatif maka ditandai adanya kecenderungan menjauh, menghindar, membenci dan tidak menyukai obyek tersebut (Kemendikbud, 2015).

Sikap dapat dibagi menjadi dua dimensi, yaitu sikap spiritual dan sosial. Sikap spiritual merupakan kecenderungan merespon secara konsisten (suka maupun tidak suka) suatu obyek sikap yang mencakup keyakinan, ibadah, penghayatan, maupun pengamalan ajaran Islam. Dengan sikap ini, diharapkan agar siswa yang dilahirkan melalui proses pendidikan benar-benar memiliki iman dan taqwa dalam arti yang sesungguhnya, yakni menjalankan segala perintah Allah dan menjauhi segala larangan-Nya. Siapa pun orangnya yang belajar matematika, maka ia harus mampu menjadikan matematika sebagai sarana untuk mengingat Allah SWT (dzikrullah). Salah satu media yang dapat digunakan untuk menjadikan matematika sebagai wasilah berdzikir kepada Allah SWT adalah melalui alQur'an al-Karim (Fathani, 2017).

Orang yang belajar matematika, berarti mereka juga tergolong orang-orang yang berfikir (tafakkur). Namun, berpikir yang dimaksud bukan berpikir keilmuan matematika semata. Akan tetapi, juga menghadirkan prinsip-prinsip ilahiyah dalam matematika (Kartanegara, 2005). Dengan demikian, maka seorang yang telah belajar matematika pada akhirnya mampu menggunakan matematika sebagai wasilah untuk memikirkan alam semesta sebagai bukti atas kebesaran dan kemahakuasaan Allah SWT.

Sikap berikutnya yang akan dimiliki oleh orang yang belajar matematika adalah amal shaleh, sebagai turunan dari dzikirullah dan tafakkur. Artinya, jika seorang siswa yang telah melaksanakan dzikir dan fikir secara sempurna, maka ia dapat berlanjut untuk melakukan amal shaleh. Hal ini sebagai wujud hubungan sesama manusia (habl min al-naas) yang merupakan implemantasi dari hubungan dengan sang Khalik (habl min Allah). Demikan, sikap-sikap spiritualitas yang dapat terbentuk ketika siswa usai mempelajari matematika.

Selanjutnya, terkait sikap sosial, sikap ini merupakan kesadaran siswa yang memengaruhi perbuatan yang nyata dalam kegiatan-kegiatan sosial yang mencakup dimensi peer-relation, self-management, academic, complience, dan assetion. Peer-relation ditunjukkan melalui perilaku yang positif terhadap teman sebaya seperti memuji atau menasehati orang lain, menawarkan bantuan kepada orang lain, dan bermain bersama orang lain. Self-management, merefleksikan siswa yang sedang dalam fase remaja memiliki emosional yang baik, mampu untuk mengontrol emosinya, mengikuti peraturan dan batasanbatasan yang ada, dan dapat menerima kritikan secara baik. Academic merupakan dimensi sosial yang ditunjukkan melalui pemenuhan tugas secara mandiri, menyelesaikan tugas individual, dan mampu menjalankan arahan guru secara baik. Dimensi compliance memiliki ciri-ciri mampu mengikuti peraturan dan harapan, menggunakan waktu dengan baik, dan membagikan sesuatu kepada orang lain. Dimensi terakhir yakni assertion, didominasi oleh kemampuan-kemampuan yang membuat seorang siswa dapat menampilkan perilaku yang tepat dalam situasi yang diharapkan.

\section{METODE}

Tulisan ini merupakan hasil studi kepustakaan (library research), dengan cara mengumpulkan buku-buku ataupun jurnal yang terkait dengan penilaian sikap. Selanjutnya, buku dan jurnal yang terkumpul dicatat bagaian-bagian penting yang mendukung tulisan ini dan dikompilasi menjadi suatu tulisan. Namun, contoh-contoh yang diberikan dalam tulisan ini merupakan hasil perpaduan karya-karya guru terpilih di Indonesia ketika penulis menjadi pendamping penulisan Juknis (Petunjuk Teknis) penilaian hasil belajar Kurikulum 2013 di Kementerian Pendidikan.

\section{PENILAIAN SIKAP}

Penilaian sikap (attitude assessment) merupakan kegiatan yang bersifat kompleks, karena berkaitan dengan value dan obyeknya tidak langsung dapat diukur. Hasil penilaian sikap harus dipahami sebagai proses (outcome) bukan sebagai hasil (output) proses 
pembelajaran yang instan dinilai oleh pendidik pada setiap kali menyelesaikan proses pembelajaran. Oleh karenanya, penilaian ini merupakan proses akumulatif yang bersifat judgmental pendidik terhadap perilaku siswa selama periode waktu tertentu (misalnya setengah atau satu semester) yang didasarkan pada pengamatan dan rekaman tertentu dengan indikator perilaku yang ditetapkan.

Dalam konteks pembelajaran matematika, penilaian sikap yang utama dilakukan oleh guru dengan menggunakan teknik pengamatan (selama proses pembelajaran pada jam pembelajar-an). Selebihnya dapat dilengkapi informasinya oleh guru BK dan wali kelas (selama siswa di luar jam pelajaran), dan hasilnya dituangkan dalam jurnal (mencakup catatan anekdot atau anecdotal record atau catatan kejadian atau incidental record), serta informasi lain yang valid dan relevan. Jurnal tidak hanya didasarkan pada apa yang dilihat secara langsung oleh guru matematika, wali kelas, dan guru BK, namun juga informasi lain yang relevan dan valid yang diterima dari berbagai sumber. Penilaian diri dan penilaian antarteman dapat dilakukan oleh guru matematika dalam rangka pembentukan karakter sikap, yang hasilnya dapat dijadikan sebagai salah satu konfirmasi dan sifatnya sebagai penunjang. Skema penilaian sikap dapat dilihat pada Gambar 1 berikut.

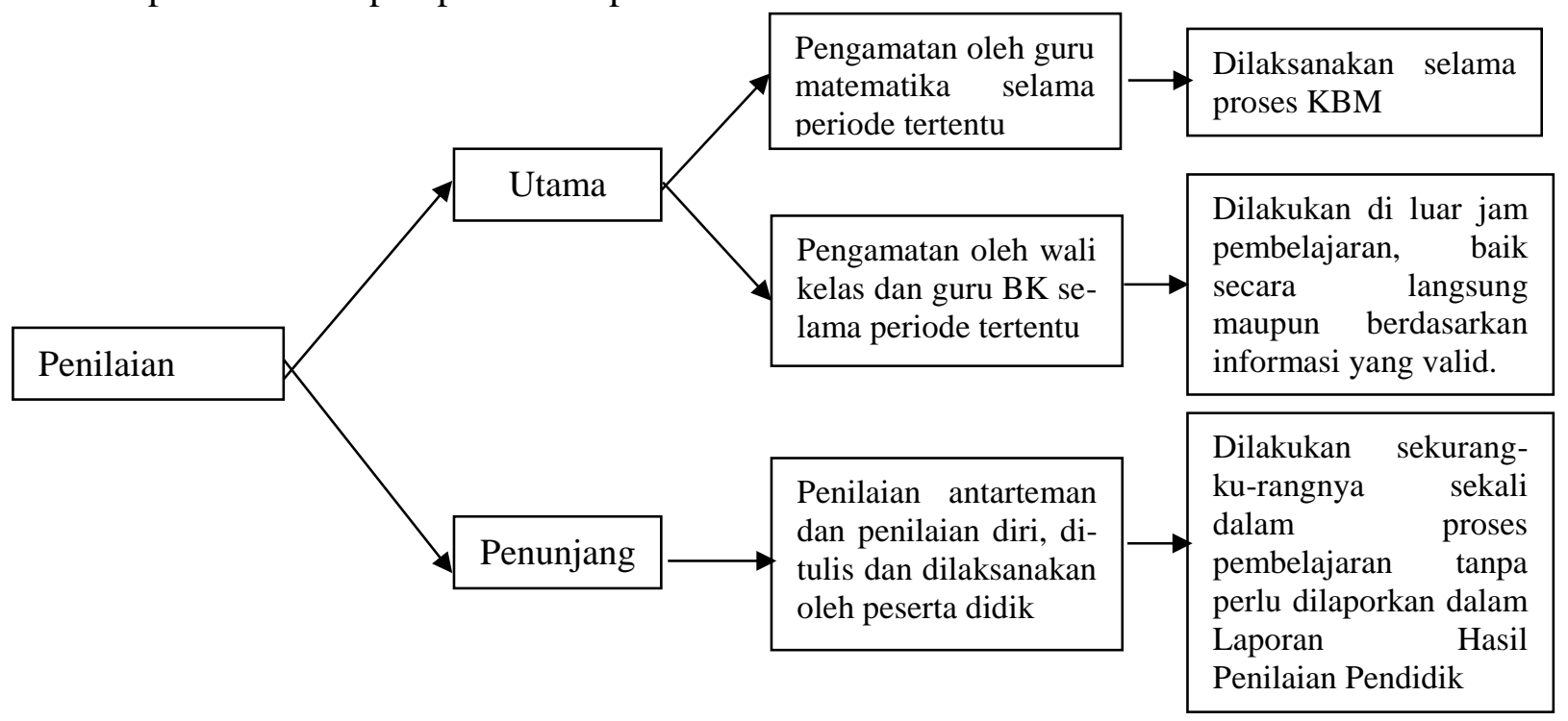

\section{Gambar 1 Skema Proses Penilaian Sikap}

Pengamatan sebagai teknik utama dalam melakukan penilaian sikap, dalam pelaksanaanya perlu didukung oleh iklim sekolah/madrasah dan organisasi yang baik. Artinya, sekolah/ madrasah sebagai institusi penyelenggara pembelajaran perlu melakukan perencanaan dalam pengembangan dan pembinaan sikap yang disesuaikan dengan visi misi sekolah/madrasah melalui beberapa tahapan: (1) Penentuan aspek sikap spiritual yang akan dinilai, disesuaikan dengan visi misi sekolah/madrasah sebagai tujuan pembelajaran, pembinaan dan pembentukan sikap, dan (2) Pengintegrasian aspek sikap dalam pembelajaran. Sebagai bagian dari aktivitas belajar mengajar, menilai sikap hanya dapat ditangkap ketika sikap tersebut muncul di permukaan. Upaya yang dapat dilakukan untuk memunculkan sikap adalah memberikan stimulus terhadap sikap (Kemendikbud, 2015). Oleh karena itu, memunculkan sikap perlu dilakukan setting wahana situasi yang dapat dibagi pelaksanaanya di dalam dan di luar kelas.

Dalam konteks seperti ini, sekolah/madrasah perlu menjadi tempat yang menyenangkan dan kondusif bagi siswa belajar. Hal itu dapat terjadi apabila sekolah/madrasah dapat menyemai bibit-bibit positif melalui proses pembelajaran dan 
membentuk sikap spiritual serta sosial siswa melalui contoh-contoh perilaku orang-orang yang ada di dalamnya. Itu akan sangat membantu dalam pengembangan sikap siswa.

Siswa merupakan pembelajar konstruktif. Mereka belajar paling baik melalui melakukan. Untuk membangun sikap yang baik, siswa memerlukan banyak kesempatan untuk menerapkan rasa sosial, tanggung jawab, jujur, dan keadilan dalam interaksi sehari-hari dan dalam diskusi-diskusi. Dalam praktik di sekolah/madrasah, hal ini dapat dilakukan melalui praktik bagaimana membangun kelompok belajar koperatif, membangun konsensus dalam pertemuan kelas, mengurangi pertentangan dalam suatu permainan, dan bagaimana semangat kebersamaan dan kepedulian sesama.

Perilaku positif di sekolah/madrasah tersebut dapat terinternalisasi secara baik, apabila perilaku positif senantiasa dicontohkan, diajarkan dan diingatkan. Dalam jangka panjangnya, perilaku positif itu akan diadopsi oleh siswa menjadi perilaku yang baik sesuai harapan masyarakat. Oleh karenanya, semua pihak yang berperan di sekolah/madrasah perlu memperhatikan tindak tanduknya.

Mengacu uraian sebelumnya, maka enilaian sikap dalam mata pelajaran matematika secara umum dapat dilakukan dalam kaitannya dengan berbagai obyek sikap yang menurut Zakaria (2011) dan Setiadi (2016) sebagai berikut. Pertama, sikap terhadap mata pelajaran matematika. Siswa perlu memiliki sikap positif terhadap pelajaran matematika. Dengan sikap positif dalam diri siswa akan tumbuh dan ber-kembang minat belajar, akan lebih mudah diberi motivasi, dan akan lebih mudah menyerap materi pelajaran yang diajarkan (Kusaeri \& Cahyan, 2017). Oleh karena itu, guru perlu menilai tentang sikap siswa terhadap mata pelajaran yang diajarkannya.

Kedua, sikap terhadap guru matematika. Siswa perlu memiliki sikap positif terhadap guru matematika, yang mengajarnya. Siswa yang tidak memiliki sikap positif terhadap guru, akan cenderung mengabaikan hal-hal yang diajarkan. Dengan demikian, siswa yang memiliki sikap negatif terhadap guru pengajar akan sukar menyerap materi matematika yang diajarkan oleh guru tersebut. Ketiga, sikap terhadap proses pembelajaran. Siswa juga perlu memiliki sikap positif terhadap proses pembelajaran matematika yang berlangsung. Proses pembelajaran di sini mencakup: suasana pembelajaran, strategi, metodologi, dan teknik pembelajaran yang digunakan. Tidak sedikit siswa yang merasa kecewa atau tidak puas dengan proses pem-belajaran yang berlangsung, namun mereka tidak mempunyai keberanian untuk menyatakan. Akibatnya, mereka terpaksa mengikuti proses pembelajaran yang berlangsung dengan perasaan yang kurang nyaman. Hal itu dapat memengaruhi penyerapan materi pelajarannya.

Keempat, sikap terhadap materi dari pokok-pokok bahasan yang ada. Siswa juga perlu memiliki sikap positif terhadap materi yang diajarkan, yang menjadi kunci keberhasilan proses pembelajaran. Kelima, sikap berhubungan dengan nilai-nilai tertentu yang ingin ditanamkan dalam diri siswa melalui materi suatu pokok bahasan tertentu dalam matematika. Misalnya, pengajaran pokok bahasan aritmetika sosial. Berhubungan dengan pokok bahasan ini, ada nilai luhur tertentu yang relevan diajarkan dan diinternalisasikan dalam diri siswa. Misalnya: tekun, kerja sama, disiplin, teliti, hemat, dan sebagainya.

\section{IMPLEMENTASI DAN CONTOH PENILAIAN SIKAP DALAM MATEMATIKA}

Sebagaimana diuraikan sebelumnya, untuk menilai sikap siswa dapat menggunakan metode pengamatan, penilaian diri, penilaian antarteman dan jurnal. Masing-masing dari metode tersebut akan dipaparkan secara ringkas dan disertasi contoh implementasinya.

\section{1) Lembar Pengamatan (Observasi)}

Observasi merupakan teknik penilaian yang dilakukan secara berkesinambungan dengan menggunakan indera, baik secara langsung maupun tidak langsung dengan menggunakan instrumen yang berisi sejumlah indikator perilaku yang diamati. Observasi 
langsung dilaksanakan oleh guru secara langsung tanpa perantara orang lain. Sedangkan observasi tidak langsung dengan bantuan orang lain, seperti guru lain, orang tua, peserta didik, dan pihak-pihak lain yang ada di sekolah.

Bentuk instrumen yang digunakan untuk observasi adalah pedoman observasi yang berupa daftar cek atau skala penilaian (rating scale) yang disertai rubrik. Daftar cek digunakan untuk mengamati ada tidaknya suatu sikap atau perilaku. Sedangkan skala penilaian menentukan posisi sikap atau perilaku siswa dalam suatu rentangan sikap. Pedoman observasi secara umum memuat pernyataan sikap atau perilaku yang diamati dan hasil pengamatan sikap atau perilaku sesuai kenyataan. Pernyataan memuat sikap atau perilaku yang positif atau negatif sesuai indikator penjabaran sikap dalam kompetensi inti dan kompetensi dasar. Rentang skala hasil pengamatan antara lain dapat berupa: (1) selalu, sering, kadang-kadang, tidak pernah; (2) sangat baik, baik, cukup baik, kurang baik, atau masih banyak skala lain yang berkembang.

Berikut disajikan contoh instrumen untuk melakukan observasi sikap spiritual dan sikap pada matematika.

\section{Contoh 1. Pedoman Observasi Sikap Spiritual}

\section{Petunjuk}

1. Berilah tanda $(\sqrt{ })$ pada kolom sesuai sikap spiritual yang muncul pada diri siswa, dengan kriteria sebagai berikut.

Selalu : Apabila selalu melakukan sesuai pernyataan

Sering : Apabila sering melakukan dan kadang-kadang tidak melakukan

Kadang-kadang : Apabila kadang-kadang melakukan dan sering tidak melakukan

Tidak Pernah : Apabila tidak pernah melakukan

2. Lembaran ini diisi oleh guru.

Nama Siswa

Kelas/Materi

Tanggal Pengamatan :

\begin{tabular}{|c|c|c|c|c|c|}
\hline \multirow[t]{2}{*}{ No. } & \multirow[t]{2}{*}{ Aspek Pengamatan } & \multicolumn{4}{|c|}{ Kategori } \\
\hline & & Selalu & Sering & $\begin{array}{l}\text { Kadang- } \\
\text { kadang }\end{array}$ & $\begin{array}{r}\text { Tidak } \\
\text { Pernah }\end{array}$ \\
\hline 1. & $\begin{array}{l}\text { Berdoa sebelum dan sesudah melakukan } \\
\text { sesuatu }\end{array}$ & & & & \\
\hline 2. & $\begin{array}{l}\text { Memberi salam sebelum dan sesudah } \\
\text { menyampaikan pendapat }\end{array}$ & & & & \\
\hline 3. & Tidak menyontek ketika ujian & & & & \\
\hline 4. & $\begin{array}{l}\text { Tidak melihat jawaban teman ketika } \\
\text { ujian }\end{array}$ & & & & \\
\hline 5. & $\begin{array}{l}\text { Merasakan kebesaran Allah (tidak } \\
\text { sombong) setelah mempelajari mate- } \\
\text { matika }\end{array}$ & & & & \\
\hline
\end{tabular}

\section{Contoh 2. Lembar Observasi Sikap}

\section{Petunjuk}

1. Berilah angka (1, 2, 3 atau 4) pada kolom yang sesuai sikap yang muncul pada diri siswa, dengan kriteria sebagai berikut.

4 : Apabila selalu konsisten menunjukkan sikap sesuai aspek sikap

3 : Apabila sering konsisten menunjukkan sikap sesuai aspek sikap dan kadang-kadang tidak sesuai aspek sikap

2 : Apabila kadang-kadang konsisten menunjukkan aspek sikap dan sering sesuai aspek aspek sikap 
1 : Apabila tidak pernah konsisten menunjukkan sikap sesuai aspek sikap

2. Lembaran ini diisi oleh guru.

\section{Hari/Tanggal}

Kelas/Materi

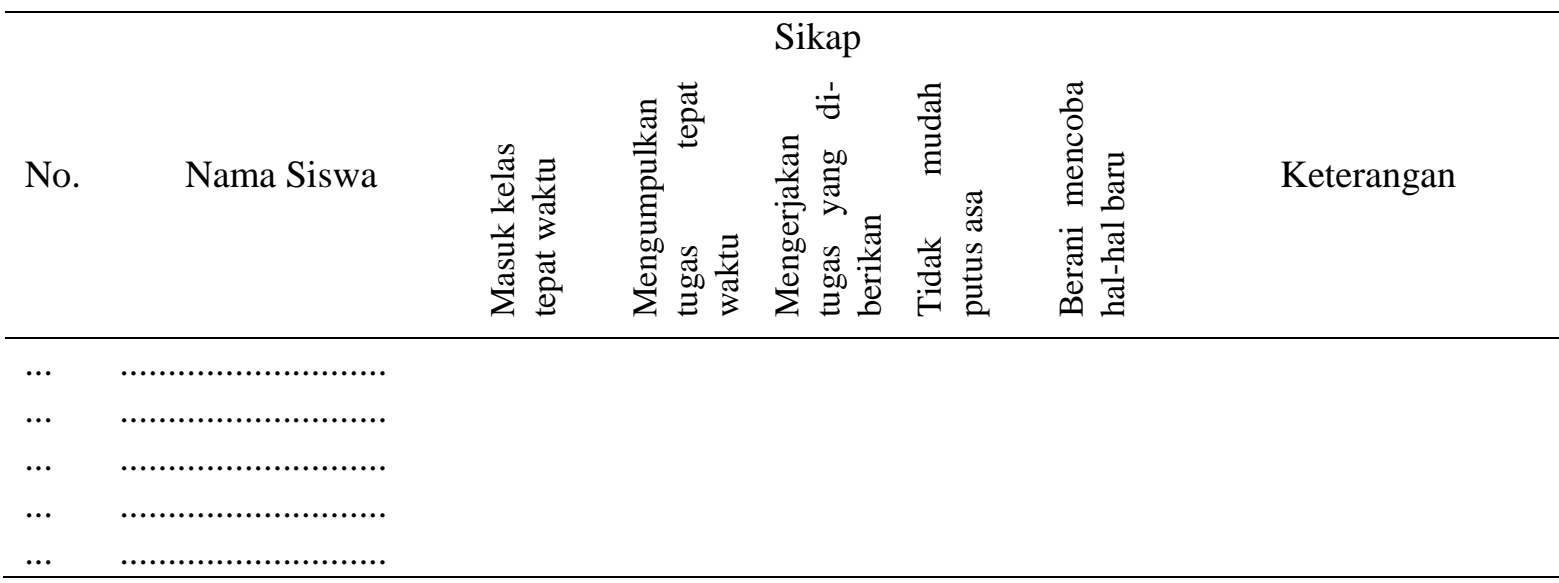

\section{2) Penilaian Diri}

Penilaian diri merupakan teknik penilaian dengan cara meminta peserta didik untuk mengemukakan kelebihan dan kekurangan dirinya dalam konteks pencapaian kompetensi. Instrumen yang digunakan berupa lembar penilaian diri menggunakan daftar cek atau skala penilaian (rating scale) yang disertai rubrik.

Skala penilaian dapat disusun dalam bentuk skala Likert atau skala semantic differential. Skala Likert adalah skala yang dapat dipergunakan untuk mengukur sikap, pendapat, dan persepsi seseorang atau sekelompok orang mengenai suatu gejala atau fenomena. Sedangkan skala semantic differential yaitu skala untuk mengukur sikap, tetapi bentuknya bukan pilihan ganda maupun checklist, tetapi tersusun dalam satu garis kontinum di mana jawaban yang sangat positif terletak dibagian kanan garis, dan jawaban yang sangat negatif terletak di bagian kiri garis, atau sebaliknya.

Data yang diperoleh melalui pengukuran dengan skala semantic differential adalah data interval. Skala bentuk ini biasanya digunakan untuk mengukur sikap atau karakteristik tertentu yang dimiliki seseorang. Kriteria penyusunan lembar penilaian diri:

(a) Pertanyaan tentang pendapat, tanggapan dan sikap, misalnya: sikap responden terhadap sesuatu hal.

(b) Gunakan kata-kata yang sederhana dan mudah dimengerti oleh responden.

(c) Usahakan pertanyaan yang jelas dan khusus.

(d) Hindarkan pertanyaan yang mempunyai lebih dari satu pengertian,

(e) Hindarkan pertanyaan yang mengandung sugesti,

(f) Pertanyaan harus berlaku bagi semua responden

\section{Contoh 3. Lembar Penilaian Diri}

\section{Petunjuk}

Berilah tanda $(\sqrt{ })$ pada kolom sesuai dengan kondisi Anda, dengan ketentuan sebagai berikut.

Selalu : Apabila selalu melakukan sesuai pernyataan

Sering : Apabila sering melakukan dan kadang-kadang tidak melakukan

Kadang-kadang : Apabila kadang-kadang melakukan dan sering tidak melakukan

Tidak Pernah : Apabila tidak pernah melakukan 


\begin{tabular}{|c|c|c|c|c|c|}
\hline \multirow{2}{*}{ No. } & \multirow{2}{*}{ Aspek } & \multicolumn{4}{|c|}{ Skala } \\
\hline & & 1 & 2 & 3 & 4 \\
\hline 1. & Saya senantiasa masuk kelas tepat waktu & & & & \\
\hline 2. & $\begin{array}{l}\text { Saya mengerjakan tugas-tugas yang diberikan } \\
\text { guru }\end{array}$ & & & & \\
\hline 3. & Saya mengumpulkan tugas tepat waktu & & & & \\
\hline 4. & $\begin{array}{l}\text { Saya tidak mudah putus asa ketika dihadapkan } \\
\text { pada soal matematika }\end{array}$ & & & & \\
\hline 5. & $\begin{array}{l}\text { Saya berani mencoba cara-cara baru ketika } \\
\text { diminta menyelesaikan soal-soal matematika }\end{array}$ & & & & \\
\hline
\end{tabular}

\section{3) Penilaian Antarteman}

Penilaian antarteman merupakan teknik penilaian dengan cara meminta peserta didik untuk saling menilai terkait dengan pencapaian kompetensi. Instrumen yang digunakan untuk penilaian antarteman adalah daftar cek dan skala penilaian (rating scale) dengan teknik sosiometri berbasis kelas. Guru dapat menggunakan salah satu dari keduanya atau menggunakan dua-duanya.

\section{Contoh 4. Lembar Penilaian Antarteman}

\section{Petunjuk}

Berilah tanda $(\sqrt{ })$ pada kolom sesuai dengan kondisi teman Anda.

Nama Siswa Yang Dinilai Kelas/Materi

\begin{tabular}{clc}
\hline \multirow{2}{*}{ No. } & \multicolumn{1}{c}{ Aspek } & \multicolumn{2}{c}{ Melakukan } \\
& & Ya \\
\hline 1. & Masuk kelas tepat waktu \\
2. & Mengerjakan tugas-tugas yang diberikan guru & \\
3. & Mengumpulkan tugas tepat waktu & \\
4. & Tidak mudah menyerah ketika dihadapkan pada soal matematika & \\
5. & Mencoba cara-cara baru ketika diminta menyelesaikan soal-soal & \\
& matematika
\end{tabular}

\section{4) Jurnal}

Jurnal merupakan catatan guru di dalam dan di luar kelas yang berisi informasi hasil pengamatan tentang kekuatan dan kelemahan siswa yang berkaitan dengan sikap dan perilaku. Kelebihan yang ada pada jurnal adalah peristiwa/kejadian dicatat dengan segera. Dengan demikian, jurnal bersifat asli dan objektif dan dapat digunakan untuk memahami siswa dengan lebih tepat. sementara itu, kelemahan yang ada pada jurnal adalah reliabilitas yang dimiliki rendah, menuntut waktu yang banyak, perlu kesabaran dalam menanti munculnya peristiwa sehingga dapat mengganggu perhatian dan tugas guru, apabila pencatatan tidak dilakukan dengan segera, maka objektivitasnya berkurang.

Terkait dengan pencatatan jurnal, maka guru perlu mengenal dan memperhatikan perilaku siswa baik di dalam kelas maupun di luar kelas. Aspek-aspek pengamatan ditentukan terlebih dahulu oleh guru sesuai dengan karakteristik mata pelajaran yang diajar. Aspekaspek pengamatan yang sudah ditentukan tersebut kemudian dikomunikasikan terlebih dahulu dengan siswa di awal semester.

\section{Contoh 5. Penilaian dengan Jurnal}

\section{Isian Jurnal}

\begin{tabular}{ll} 
Nama Siswa & : Dante \\
Tanggal Kejadian & $:$ 30 Agustus 2017 \\
Aspek yang diamati & $:$ Kejujuran \\
\hline
\end{tabular}




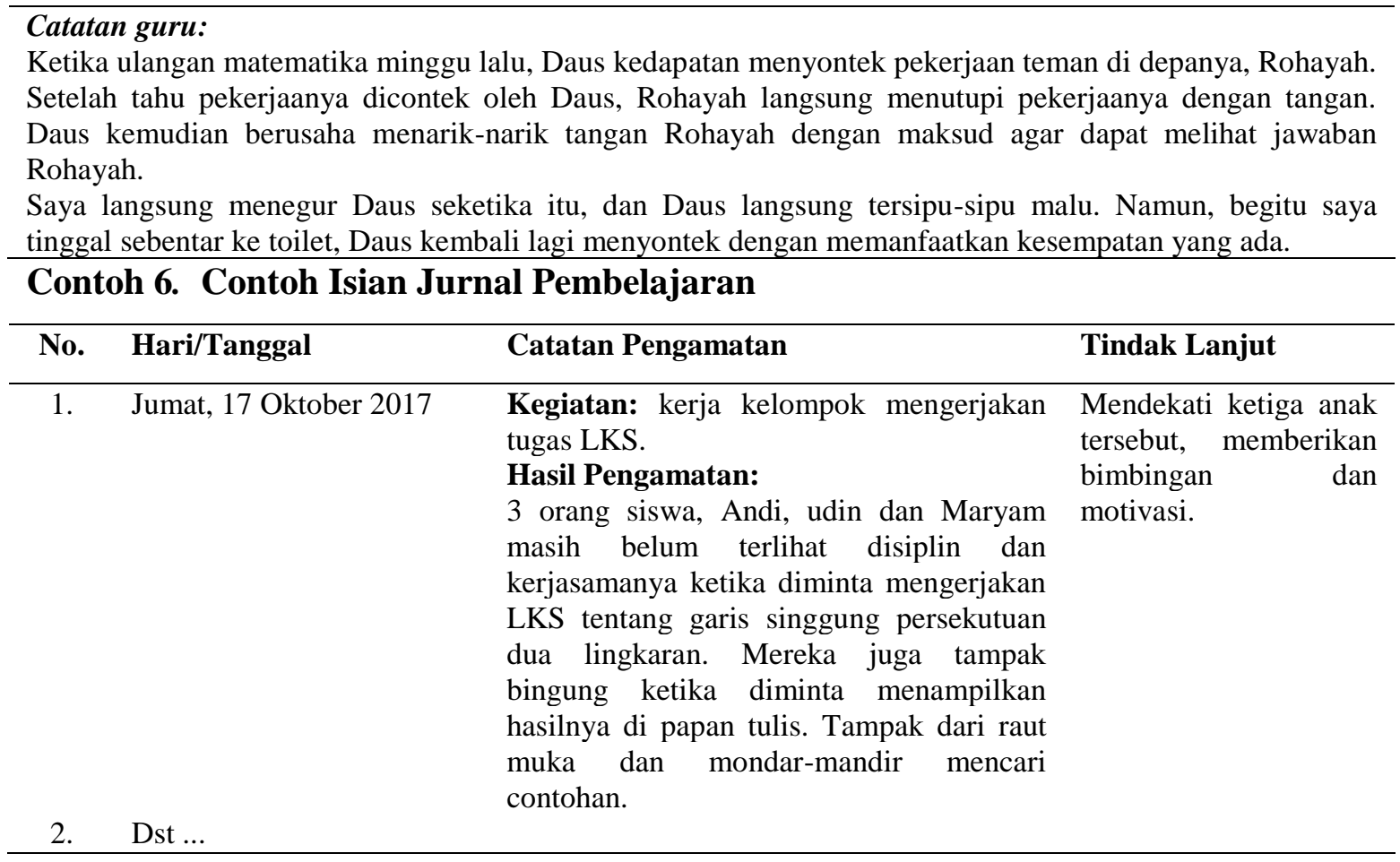

\section{SIMPULAN DAN SARAN}

Demikianlah uraian singkat terkait penilaian sikap spiritual dan sosial dalam konteks pembelajaran matematika. Tentu contoh-contoh yang disajikan masih perlu dilengkapi dengan contoh yang lebih komprehensif, sehingga aspek-aspek sikap yang begitu kompleks dapat terkuak. Perlu ditekankan bahwa, yang paling sulit untuk mengukur dan mengembangkan instrumen dalam konteks ini adalah sikap spiritual siswa, sebab nilai-nilai matematika sangat sulit untuk diarahkan ke sana.

\section{DAFTAR RUJUKAN}

Abidin, Y. (2012). Model Penilaian Otentik dalam Pembelajaran Membaca Pemahaman Berorientasi Pendidikan Karakter. Jurnal Pendidikan Karakter, 2(2),164-178.

Chen, Q. (2011). Assessment policy change in relation to English language teaching and learning in China: Study of perspectives from two universities. Dissertation unpublised. Queensland: Queensland University of Technology.

Clarke, D. (1996). Assessment, in A.J. Bishop, K. Clements, C. Keitel, J. Kilpatrick and C. Laborde (eds.) International Handbook of Mathematics Education, (pp. 327-370). Kluwer, Dordrecht.

Fathani, A.H. (2017). Matematikawan Ulul Albab: Membumikan Matematika dalam Dimensi Spiritual, Teoritis, dan Aplikatif. Diakses dari https://www.researchgate. net/publication /318340019 tanggal 08 April 2018.

Fernandes, H. J. X. (1984). Testing and Measurement. Jakarta: National Educational Planning, Evaluation and Curriculum Development.

Fulcher dan Davidson. (2007). Language Testing and Assessment: An Advanced Resource Book. New York: Routledge.

Kemendikbud RI. (2015). Penilaian Sikap Spiritual dan Sosial. Jakarta: Pusat Penilaian Pendidikan Balitbang Kementerian Pendidikan dan Kebudayaan Republik Indonesia.

Kartanegara, M. (2005). Integrasi Ilmu: Sebuah Rekonstruksi Holistik. Bandung: Mizan dan UIN Jakarta Press.

Kusaeri, K. (2014). Acuan \& Teknik Penilaian Proses \& Hasil Belajar dalam Kurikulum 2013. Yogyakarta: Ar-Ruzz Media. 
Kusaeri, K., \& Cahyan, E. D. H. (2017). Sikap, Harapan dan Persepsi Siswa pada Matematika serta Implikasinya terhadap Kemampuan Regulasi Diri. Jurnal Pengajaran MIPA, 21(2), 114-121.

Kusaeri, K., Sutini, S., Suparto, S., \& Wardah, F. (2019). The validity and inter-rater reliability of project assessment in mathematics learning. Beta: Jurnal Tadris Matematika, 12(1), 1-13.

Park, J.S \& Park H.P. (2012). The Changes of Assessment at Middle School Level in Korea. ZDM Mathematics Education, 44, 201-209.

Peraturan Menteri Pendidikan dan Kebudayaan Republik Indonesia Nomor 23 Tahun 2016 tentang Standar Penilaian Pendidikan. Jakarta: Badan Standar Nasional Pendidikan Kementerian Pendidikan dan Kebudayaan RI.

Retnawati, H. (2015). Hambatan guru matematika Sekolah Menengah Pertama dalam menerap-kan kurikulum baru. Cakrawala Pendidikan, 34(3), 390-403.

Setiadi, H. (2016). Pelaksanaan Penilaian pada Kurikulum 2013. Jurnal Penelitian dan Evaluasi Pendidikan, 20(2), 166-178.

Watt, H. (2005). Attitudes to The Use of Alternative Assessment Methods in Mathematics: A Study with Secondary Mathematics Teachers in Sydney, Australia. Educational Studies in Mathematics, 58(1), 21-44.

Wormeli, R. (2006). Fair Isn't Always Equal:Assessing \& Grading in the Differentiated Classroom. Ohio: NMSA.

Zakaria, R. T. (2011). Penilaian Sikap. Jakarta: Pusat Penilaian Pendidikan Balitbang Kementerian Pendidikan dan Kebudayaan RI. 